\title{
Consequences of Imprisonment and Possibilities of Influence on Perpetrator in the Conditions of Penitentiary Isolation
}

\author{
Gerald G. Sander \\ University of Applied Sciences — Public Administration and Finance in Ludwigsburg, Germany \\ Pawet Kobes \\ University of Warsaw, Poland
}

\begin{abstract}
Imprisonment which is implemented in the present form in European countries has reached its capabilities in terms of re-socialisation, if any function apart from isolating might have been achieved. This has happened because the specificity of penitentiary isolation results in individuals being unable to acquire real-skills to live in the society in accordance with its rules. The paradox of this penalty is that its conditioning favours the destruction of a human, the loss of their ability to function in society rather than their re-socialisation and building the appropriate social attitudes. Prisonisation which affects each prisoner to varying degrees is mostly to blame, but also other elements inseparably connected with penitentiary isolation. In order to mitigate the influence of negative factors it is necessary to implement the appropriate mechanisms, which, however, are not able to eliminate negative effects of imprisonment, but they are able to mitigate them, as already indicated. The aim of the following publication is an attempt to find a solution, identify which factors negatively influence re-socialisation of prisoners in penitentiary isolation and if there are still any possibilities to improve the system of execution of imprisonment sentence before the penalty in its present form disappears from legal systems. The authors also ask a question: Can a man be taught to live in society in accordance with the rules accepted by it, in spite of the sometimes long-term isolation of this man from the society?
\end{abstract}

DOI: $10.5604 / 01.3001 .0012 .1705$

http://dx.doi.org/10.5604/01.3001.0012.1705

Keywords: penalty, prison, convict, prisonisation, re-socialisation

\section{Introduction}

The voices concerning the necessity to limit the penalty of imprisonment as a response to human criminal behaviour and the simultaneous introduction of alternative mechanisms as a reaction to criminal actions are getting louder and louder. The criticism of the modern model of execution of prison sentences is a result of statements claiming that the present model applied in Europe serves more to preserve negative attitudes and at the same time hinders the re-socialisation process.

Therefore, the aim of the following publication is to answer the question: which factors negatively influence the re-socialisation of those imprisoned and whether there is any way to improve the system of execution of a prison sentence before this penalty, in its present form, disappears from legal systems? Can a man be taught to live in a society in accordance with the rules accepted by it despite a sometimes long-term isolation of this man from society? 


\section{Effects of Imprisonment on the Psychosocial Development of Prisoners}

Imprisonment has numerous negative effects for an inmate as a consequence of which the re-socialisation activities directed at them will not bring proper results or, even worse, they may cause regression of mental development.

Such a state of affairs results from the fact that a prison is a type of a total institution and the most important characteristic of such an institution is the violation of all barriers separating three basic spheres of life, in which, according to E. Goffman, individuals sleep, have fun and work in different places, with different partners, under different authority and without any rational plan enforced from above. ${ }^{1}$ This is in contrast with the case of a total institution where all daily activities are performed in the same place with the same superiors. What is more, every moment these activities are performed a person is not alone, because everything takes place in the company of others, whereby each of these persons is treated the same and the same things are required from them. Apart from that, everyday activities are strictly scheduled in a way that each of them inevitably leads to another pre-planned activity that will take place immediately after it. ${ }^{2}$

The results of the research conducted on the functioning of prisons as a whole and the programmes of execution of prison sentences indicate that the internal organisation of these penitential units favours the dehumanisation of prisoners to a larger degree than improvement of their attitudes ${ }^{3}$.

Isolating individuals in penitential institutions significantly or completely precludes satisfying the physical needs of a human. By restricting the functioning of people in this way they then experience extreme isolation, which is an inherent feature of imprisonment. Such isolation might be perceived as a specific form of a difficult situation - a situation of deprivation. It needs to be understood as a state in which a human is deprived of something which is essential to lead a normal life. Isolation simultaneously deprives the individual of different human needs, starting with basic needs, through psychogenic needs to psychosocial needs. Apart from triggering a typical frustration-anger mechanism, which is typical of the state of unmet needs, it also causes negative - in respect of health - conditioned responses. Excitability in reaction of the centres responsible for urges and emotions builds up, with the concurrent decline in the number of processes occurring in the other areas of the organism. Persons deprived of liberty are characterised by increased emotional reactions combined with the process of suppressing them, but also participation of emotional and affective reactions, which significantly limits participation in the mental functioning of a human. The dominance of the processes which suppress urges and emotions over the processes of their activation disorganises the functioning of this mechanism in the brain, which has an influence on decreasing the general functioning efficiency of a human's personality and creating organic damage to the brain tissue. Penitential isolation has a direct

\footnotetext{
${ }^{1}$ Goffman E, Instytucje totalne. Sopot, 2011, p. 16.

2 Ibid., p. 16.

${ }^{3}$ Bałandynowicz A, Probacja. Sprawiedliwość karząca. Warsaw, 2015, p. 180.
} 
impact on causing neurotic states which hinder pedagogic influencing of prisoners and limits the strength of a prisoner's adaptation to living in an open society. Besides, anxieties and a constant feeling of danger, which are the result of isolation, have an impairing effect on the course of intellectual processes, but also contribute to impoverishment and stereotyping. ${ }^{4}$

The element which really negatively influences a life in isolation is the overcrowding of prisons which effects people's moods. The negative effects of overcrowding include: ${ }^{5}$

a) sensory overload - a lack of possibility to process information and stimuli which come from the environment,

b) limitations on spatial behaviour patterns; where penitentiaries are overpopulated, keeping one's own territory becomes a brutal fight for space in a prison cell and other places,

c) the so called behavioural dirt which is an increase in aggression, sexual hyperactivity and homosexual behaviours,

d) negative emotional states, a higher level of physiological excitement, diseases and injuries,

e) influence on behaviour, social attitudes and feelings; kindliness towards other people and the ability to help are decreased, the tendency to violence increases,

f) a growing number of incidents of violating the prison regulations,

g) no possibility to freely regulate spatial distance between prisoners; overpopulation forces convicts to keep close to others which results in negative experiences, excessive population density violates the fundamental needs of an individual, for example the feeling of privacy and intimacy.

Having the above considerations in mind, it is worth noticing that penitential isolation does not allow prisoners to choose the people with whom they are to stay with in one cell for a long period of time, which results in the fact that they are forced to live with persons of totally different backgrounds, culture and behavioural motivation. Moreover, many of the prisoners are depraved people, with a disturbed personality; those who do not recognise commonly accepted social rules. This situation makes it difficult to work out appropriate interpersonal relations, which would allow the individual's emotional needs to be satisfied. In normal conditions people stay with others because they want to, they make their choices and they want to play some social roles, which is possible thanks to these people. While being isolated in a penitentiary, however, they can hardly ever make such a choice, in some cases it is impossible. What is more, penitential isolation is a consequence of the decision taken by other people, and exercising discipline demands proper behaviour of both prison staff and convicts which, in turn, often leads to conflicts. ${ }^{6}$

${ }^{4}$ Bałandynowicz A, Probacja. System sprawiedliwego karania. Warsaw, 2002, pp. 59-60. See more on stress among inmates and its results in: Wojewoda $M$, Pomoc duchownych w przełamywaniu więziennego stresu, [in:] Szerląg A (Ed.), Kara pozbawienia wolności a readaptacja społeczna skazanych. Wrocław, 2011, pp. 115-116.

${ }^{5}$ Nawój-Sleszyński A, Przeludnienie więzień w Polsce - przyczyny, następstwa i możliwości przeciwdziałania. Łódź, 2013, p. 149.

${ }^{6}$ Sarzała D, Patologiczne zachowania więźniów w kontekście izolacji i resocjalizacji penitencjarnej. Warsaw, 2013, pp. 103-104. 
One of the negative phenomena of prison isolation is the functioning of the 'second life', which is connected with the mechanism of demoralising needs. Joining an informal group guarantees satisfying the needs of safety, affiliation and recognition, thus the needs which convicts feel a lack of the most. The phenomenon of the 'second life' is a form of a destructive integration of prisoners who by means of creating a specific social structure simultaneously accept, cultivate and build a deviant subculture. It is reflected in a specific and conflict system of values which is based on violence, loutishness and slyness, as well as absolute solidarity, rigour and brutality. The system is in contrast to that which is the socially accepted one. A separate language, system of standards and sanctions are typical of it. The harmfulness of the phenomenon is expressed in spreading negative stereotypes of codes of conduct founded on values which have lost their real meaning. Certainly, it is a process which is in opposition to re-socialisation directed at making convicts familiar with the culture, socially accepted system of values, as well as preparing prisoners for performing constructive social functions. Thus the organised prison subculture creates negative attitudes, it strengthens socially unaccepted patterns of meeting needs and it leads to internalisation of an anti-social normative system, whereas attempts to counteract these processes by prison personnel are usually ineffective. ${ }^{7}$

The prison subculture develops most in penitentiary institutions for juveniles. It is mostly this group of convicts who carry subcultural principles, and it is these who very often determine unlawful life behind the bars. Juvenile offenders frequently follow the rules of the 'second life' in a fanatical way. While re-offenders aim at the stability of their prison life, young offenders go ahead and they do not pay attention to legal restrictions. ${ }^{8}$

Because they are under the influence of the processes typical of the 'second life', and independently of their relations to the prison subculture, a person staying in a penitentiary gradually adopts the rules of the prison community which regulate interpersonal relationships between convicts and other members of the prison environment. The process is called 'prisonisation' or prison adaptation which is a self-destructive system and it does not support social adaptation of criminals. ${ }^{9}$ The prisonisation means that a person staying in such isolation consequently acquires the knowledge of forms and values existing in a community of prisoners, and also their level of implementing these rules becomes greater and greater. A prisoner learns methods of survival, attitudes, the system of values, rituals and customs characteristic of the penitentiary environment. Prisonisation then helps a person assimilate with the prison community, and as a consequence, it supports blind approval of crime. On the other hand, the prisonisation mechanism makes isolation-related problems less complicated..$^{10}$

${ }^{7}$ Bałandynowicz A, Probacja. Resocjalizacja z udziałem społeczeństwa. Warsaw, 2006, pp. 71-72.

${ }^{8}$ Przybyliński S, Podkultura więzienna - wielowymiarowość rzeczywistości penitencjarnej. Cracow, 2005, pp. 55-56.

${ }^{9}$ Bałandynowicz A, Probacja. Resocjalizacja z udziałem społeczeństwa. Warsaw, 2011, p. 131.

${ }^{10}$ Ciosek M, Psychologia sądowa i penitencjarna. Warsaw, 2003, pp. 216-217. 
The phenomena discussed above, which take place in a prison facility, result in a range of negative psychological consequences which affect the whole population of convicts, including minors, to a different extent. The outcomes of prisonisation are as follows: ${ }^{11}$

1. The stigmatisation process. The first step already starts at liberty during a trial and taking a person into custody. At that time a suspect gains the information that they belong to the criminal minority of society. The second step of the stigmatisation is giving a prison sentence and sending a convict to a penal institution, which for many convicts means that they are morally isolated and condemned by the community. While being imprisoned, and also after leaving a penal institution, a person feels marked by their isolation and they frequently recall what they have done, and that they have lost their social status. Often they are treated as a worse person, as part of the underclass.

2. The standardisation process, which is a consequence of different forms of procedures established under prison rules and the executive penal code, enforcing a unified outward appearance of detainees and standardising the amount and kind of private belongings allowed in prison. All this causes people to lack the sense of individuality or uniqueness. And yet, every human being experiences the need for being somebody individual and unique. Therefore, standardisation is in conflict with the above mentioned human needs, which is the reason why people resort to various forms of behaviour, often illegal, to attract attention to themselves and, by doing this, to emphasise their individuality within a group.

3. The degradation process, which causes the inmate to become an object of manipulation, both by fellow prisoners and prison administrative staff. It involves the inmate having to report himself/ herself, demeaning behaviour and the manner in which prison staff address prisoners, which is a very humiliating experience for many of them.

4. The depersonalisation process, which is a derivative of the above mentioned processes of stigmatisation, standardisation and degradation. Depersonalisation is a subjective sense of internal transformation, which is manifested as the sense of strangeness or even as the feeling of unreality.

These extreme (from a free person's point of view) conditions of prison life result in a human being developing a natural need for survival. Being imprisoned under constant and rather monotonous conditions naturally causes an individual to develop a need to adapt to those conditions, which entails the ability to adapt to the changing external conditions, both physical and social ones, as well as the ability to achieve - under those conditions - one's important personal aims. It is assumed that it is prison recidivists who are best adapted to the prison environment because of their greater experience and previously developed adaptation mechanisms. The majority of convicts, however, are determined to develop such adaptive mechanisms. ${ }^{12}$ There are several techniques for coping with problems, hardship and inconveniences resulting from being isolated and the same time

${ }^{11}$ Ciosek M, Człowiek w obliczu izolacji więziennej. Gdańsk, 1996, pp. 161-163.

${ }^{12}$ Ciosek M, Psychologia..., p. 211. 
- a few ways of reducing differences between an environment where one is locked up and the world outside ${ }^{13}$ :

a) withdrawing from a situation as a type of adaptation involving radically cutting oneself off from the environment and focusing exclusively on oneself, one's own matters and on what is directly related to the inmate. Moreover, the type of adaptation in question entails indifference to matters which concern other people, loosening of contacts with others and the prisoner's lack of interest in the surrounding environment. Such a strategy may lead to the abuse of defence mechanisms, in the form of, among others, escaping into dreams and idealisation, and further still it may result in excessive egocentrism, prison infantilism, or even acute depersonalisation and autism;

b) tactics of defiance, which may take the form of either an uncompromising, decisive and overt approach of resistance or hostility to the prison staff, typical of the first phase of isolation, or the form of a more hidden reluctance towards the prison staff, which is manifested through being involved in the other life. These two forms usually entwine with and complement each other;

c) 'settling-in', which is a typical recidivists' tactics involving creating for oneself the possibility for some freedom of action inside prison, as well as relatively stable and bearable living conditions. According to M Ciosek, this type of adaptation can be exploited by inmates who do not experience the shock of confinement, are resilient to difficult situations, have cognitive rather than emotional orientation, and are quick at knowing their way around. Such convicts seem to be nice, endearing and helpful, thanks to which they win friendliness both on the part of their fellow inmates and prison staff;

d) conversion, the essence of which is that the convict seems to accept all viewpoints of the prison staff, is obedient, disciplined and willing to cooperate. He/she is a model, perfect inmate, who does not cause any educational problems and tends to perform different functions. This submissiveness and subordination to the prison personnel, however, is very often deceptive as such prisoners decide to put on such an attitude to secure their own interests, which usually lets them achieve their targets;

e) cold calculation, being a combination of different methods used to adapt to imprisonment, in particular the settling-in and conversion strategies. It comes down to the inmate taking advantage of the prison staff's secrets and weaknesses, as well as of fellow prisoners' habits with a view to gaining officially forbidden benefits;

f) a mechanism of suppressing the process of going through a painful situation, which involves inmates trying not to think about their home, family and freedom, avoiding any conversations about the above topics, developing an attitude of indifference to life outside the prison walls, as well as filling up the time in confinement with different forms of activity. This strategy is designed to protect oneself against very painful emotions in a situation which cannot be changed for the better.

${ }^{13}$ Ibid., pp. 212-214. 
All the above elements of the prison world have their impact also on the outcome of rehabilitation measures targeted at prisoners, the effectiveness of which is reduced by inmates themselves, prison staff and weaknesses of the penitentiary philosophy. It must be remembered that there are no universal rehabilitation methods, which would be effective for all convicts. Any action aiming to reform an offender has to be adequate for their personality type identified through diagnostic processes. Unfortunately, the reality of the Polish penitentiary system shows significant shortcomings when it comes to such a diagnosis, and the choice of measures taken towards prisoners is usually based on formal criteria. Another factor responsible for the low effectiveness of penitentiary measures is the very formula of the correctional programme implementation as the functions of Polish correctional institutions are first of all repression and isolation. The principle of individualisation is followed only to a very small degree when putting rehabilitation methods and measures in practice. Other factors lowering the effectiveness of the rehabilitation process are mistakes and an incorrect attitude on the part of prison staff. These can involve breaking the interaction with inmates, rigorous treatment, using different forms of coercion, indifference or hampering inmates' activity. Research has also shown that prisoners' involvement in the development of an individual rehabilitation programme is first of all instrumentally motivated as it gives them an opportunity to be provided with better conditions for serving the prison sentence, to be more easily granted a temporary licence to leave prison, to have a bigger chance of being released on parole and to be treated in a better manner by the prison staff. ${ }^{14}$

Summing up the aforementioned research findings on negative consequences of the execution of a custodial sentence, it is good to quote the view of $\mathrm{H}$ Machel who, analysing negative aspects of penitentiary isolation, indicates that it has a negative impact on convicts' personality (prison organisation, regulations, personnel with unfavourable attitude towards inmates, atmosphere and mutual relations among convicts). Moreover, the author claims that long-term imprisonment prisonises rather than re-socialises, without considering the prisoner's family members who are also affected by this form of punishment. In addition to this, another proof for prison weakness is re-offending in large numbers. The existing penitentiary system is old-fashioned and a scientific approach is not taken enough into consideration in the subject matter. Furthermore, prisons stigmatise exconvicts, which makes it difficult or impossible for them to be socially included. The author indicates that a lack of individualisation when performing re-socialisation activities makes them ineffective. Additionally, some forms of correctional work have been carried out for almost 200 years, however, they still remain unprofitable and this is why, according to the author, prisons can be no longer subject to reform, therefore, they constitute a passing form of punishment. However, paradoxically, so far there has been no other form ready to replace the old one. ${ }^{15}$

\footnotetext{
${ }^{14}$ Niewiadomska I, Osobowościowe uwarunkowania skuteczności kary pozbawienia wolności. Lublin, 2007, p. 264 and the following.

${ }^{15}$ Machel H, Sens i bezsens resocjalizacji penitencjarnej - casus polski. Cracow, 2006, p. 158.
} 


\section{Limits of re-socialisation in Conditions of Penitentiary Isolation}

Criticising the execution of a custodial sentence and showing its weaknesses and effectiveness, paradoxically, does not allow it to be abolished because there has been no other type of punishment developed which would replace the existing form of dealing with offenders. It implies the necessity to search for an optimal model of penitentiary re-socialisation and its limits in objectively unfavourable environments for re-socialisation, such as prisons.

To make a penitentiary institution an educational one, where re-socialisation measures are more effective and aimed at restoring opportunities for criminals to live in a community in accordance with social regulations, the following conditions need to be fulfilled ${ }^{16}$ :

1. The objective of penitentiary institutions, their organisational structure, model of executing penalties, personnel and material conditions need to be subordinated to resocialisation, which means that penitentiary institutions will prevent demoralisation of inmates and guarantee them full personal safety.

2. The concept of the execution of prison sentence has to include the opportunity for inmates to choose different forms of behaviour which they will take responsibility for - both positive and negative ones. It needs to be remembered that re-socialisation is nothing more than learning such social roles which are to prevent offenders from re-offending and allow them to readapt socially after being released from prison.

3. The penitentiary institution should have at its disposal well-qualified personnel whose professional competence will offer the opportunity to develop, organise and implement the re-socialisation process.

4. The activity of a penitentiary institution needs to include a broad and close contact of prisoners with community members and proper community support.

5. Prisoners should have regular contact with their immediate family members who, at the same time, should expect positive attitudes on behalf of convicts and support them.

6. Prisoners need to have access to paid employment to earn money for their expenses and to repay financial liabilities, thanks to which they will keep their working habits or learn to work.

7. Free time activities need to be organised in such a way that prisoners could spend it advantageously, without further demoralisation.

8. Prisoners need to be treated similarly to all other people and, what is more, imprisonment as such is a tough punishment, so it cannot be made additionally tougher. It will make it possible to maintain relations between prison personnel and inmates at the required level of culture and lack of conflicts.

${ }^{16}$ Machel H, Więzienie jako instytucja karna i resocjalizacyjna. Gdańsk, 2003, p. 51 and the following. See: Hołyst B, Bariery resocjalizacji penalnej, [in:] Hołyst B (Ed.), Problemy współczesnej penitencjarystyki w Polsce. Warsaw, 1984, p. 31 and the following. 
9. The penitentiary institution should have the required household and technical appliances which facilitate the implementation of various re-socialisation activities.

Ignoring the above mentioned requirements for an effective penitentiary re-socialisation, it is good to present positive examples of measures undertaken in penitentiary institutions. The Polish and American research findings indicate that penitentiary measures in the form of inmates' work result in the lower percentage of them re-offending. The findings of 33 surveys concerning the effectiveness of penitentiary measures in the form of employment have shown that the rate of re-offending among participants of different programmes is about $39 \%$, and among prisoners who did not attend the programmes the rate is about $50 \%$. Other surveys have indicated that at a relatively high level of effectiveness is associated with education as a re-socialisation measure. Some surveys suggest that the effectiveness of educational measures is much higher than those in the form of work. The significance of educating criminals has also been confirmed by the outcome of independent empirical analyses which have shown that re-offending decreases up to $23 \%$ when this measure is implemented. The analysis of teaching outcomes makes it possible to introduce two conclusions. The first refers to participation in educational activities. Finishing education or advanced participation in the next stages of education (e.g. promotion to the next year) results in a lower probability of re-offending. The other conclusion related to education indicates that re-offending is inversely proportional to the level of convicts' education: the higher the level of education, the lower the rate of re-offending. Broadening the knowledge as part of school education produces more results than acquiring professional qualifications, in particular when, after leaving a penitentiary institution, the person cannot find a job relevant to the qualifications gained..$^{17}$

\section{Conclusions}

Summing up, the effectiveness level of the re-socialisation process seems to be a combination of many factors. Some of them are related to the essence of a penitentiary institution being a total institution which can be characterised by the occurrence of numerous pathological phenomena, discussed in the previous subchapter, having a negative impact on the prisoners' re-socialisation process. It seems that their limitation will automatically increase the chances for effective re-socialisation. However, the most important factor determining the success of penitentiary measures taken as regards a particular convict is an individual approach which would involve his/her weaknesses and, at the same time, enhance those elements based on which his/her new social attitudes could be developed. In this sense, penitentiary institutions as a totality should be dominated by the philosophy of an individual approach to a human being, which the entire mechanism of functioning in penitentiary isolation should be subordinated to.

${ }^{17}$ Niewiadomska l, op. cit., pp. 257-258. 


\section{References}

1. Bałandynowicz A, Probacja. System sprawiedliwego karania. Warsaw, 2002.

2. Bałandynowicz A, Probacja. Resocjalizacja z udziałem społeczeństwa. Warsaw, 2006.

3. Bałandynowicz A, Probacja. Resocjalizacja z udziałem społeczeństwa. Warsaw, 2011.

4. Bałandynowicz A, Probacja. Sprawiedliwość karząca. Warsaw, 2015.

5. Ciosek M, Człowiek w obliczu izolacji więziennej. Gdańsk, 1996.

6. Ciosek M, Psychologia sądowa i penitencjarna. Warsaw, 2003.

7. Goffman E, Instytucje totalne. Sopot, 2011.

8. Hołyst B, Bariery resocjalizacji penalnej, [in:] Hołyst B (Ed.), Problemy współczesnej penitencjarystyki w Polsce. Warsaw, 1984.

9. Machel H, Więzienie jako instytucja karna i resocjalizacyjna. Gdańsk, 2003.

10. Machel H, Sens i bezsens resocjalizacji penitencjarnej - casus polski. Cracow, 2006.

11. Nawój-Sleszyński A, Przeludnienie więzień w Polsce — przyczyny, następstwa i możliwości przeciwdziałania. Łódź, 2013.

12. Niewiadomska I, Osobowościowe uwarunkowania skuteczności kary pozbawienia wolności. Lublin, 2007.

13. Przybyliński S, Podkultura więzienna — wielowymiarowość rzeczywistości penitencjarnej. Cracow, 2005.

14. Sarzała D, Patologiczne zachowania więźniów w kontekście izolacji i resocjalizacji penitencjarnej. Warsaw, 2013.

15. Wojewoda M, Pomoc duchownych w przełamywaniu więziennego stresu, [in:] Szerląg A (Ed.), Kara pozbawienia wolności a readaptacja społeczna skazanych. Wrocław, 2011.

$(m b),(a j),(a k),(t m)$

\section{About the Authors}

Gerald G. Sander, Prof. Dr. Leiter des Instituts für Angewandte Forschung (IAF), Hochschule für öffentliche Verwaltung und Finanzen Ludwigsburg, University of Applied Sciences - Public Administration and Finance. His main area of research and professional interest is public law, including European law. Correspondence: Reuteallee 36, D-71634 Ludwigsburg, Germany. E-mail: Gerald.Sander@hs-ludwigsburg.de.

Paweł Kobes, PhD, University of Warsaw - Institute of Social Prevention and Resocialisation, Poland. His main area of research and professional interest is criminal law, criminology. Correspondence: University of Warsaw, Podchorążych 20, 00-721 Warsaw, Poland. E-mail: pawel.kobes@interia.pl.

Streszczenie. Kara pozbawienia wolności, która jest wykonywana w obecnym kształcie w krajach europejskich, osiągnęła kres swoich możliwości resocjalizacji, jeżeli w ogóle można mówić o pełnieniu przez niq innych funkcji oprócz izolacyjnej. Stało się tak ponieważ, specyfika izolacji penitencjarnej powoduje, że człowiek niq objęty nie jest w stanie nabyć rzeczywistych umiejętności do życia w społeczeństwie zgodnie z jego zasadami. Paradoks tej kary polega na tym, że jej uwarunkowania bardziej sprzyjajq destrukcji człowieka, utracie przez niego zdolności do funkcjonowania w społeczeństwie niż jego resocjalizacji i budowaniu 
właściwych postaw społecznych. Winna jest temu w głównej mierze prizonizacja dotykająca w różnym stopniu każdego więźnia, jak również inne elementy nierozerwalnie zwiq̨zane z izolacją więzienną. Aby złagodzić wpływ tych negatywnych czynników potrzebne jest wdrożenie odpowiednich mechanizmów, które jednakże nie sa w stanie wyeliminować negatywnych skutków kary pozbawienia wolności, ale — jak wcześniej wskazano — je złagodzić. Celem niniejszej publikacji jest próba odpowiedzi, jakie czynniki negatywnie wpływają na resocjalizację więźniów w izolacji penitencjarnej i czy istnieja jeszcze szanse na usprawnienie systemu wykonywania kary pozbawienia wolności, zanim kara ta w obecnym kształcie zniknie z systemów prawnych? Autorzy stawiajq̨ również pytanie: (zy można człowieka nauczyć żyć w społeczeństwie zgodnie z akceptowanymi przez nie regułami, pomimo czasem wieloletniego izolowania tego człowieka od społeczeństwa?

Резюме. Мера наказания в виде лишения свободы, которая применяется в нынешнем виде в странах Европы, достигла предела эффективности исправления, если вообще можно говорить, что примемение этой меры имеет какие-либо другие задачи, кроме изоляции осужденного. Это связано со спецификой пенитенциарной изоляции, которая приводит к тому, что осужденный не может приобретать определенные навыки, чтобы жить в обществе в соответствии с его правилами. Парадокс этого вида наказания заключается в том, что его детерминанты значительно более способствуют разрушению личности, потере способности существования в обществе, чем его ресоциализации и созданию соответствующих социальных позиций. Это связано с призонизацией, касающейся в разной степени каждого заключенного, а также другими элементами пенитенциарной изоляции. Чтобы снизить уровень влияния данных негативных факторов, необходимым оказывается внедрение определенных механизмов, которые хотя не в состоянии полностью снизить негативные последствия заключения, то могут облегчить их. Целью настоящей ствтьи явялется попытка ответить на вопрос, какие факторы негативно влияют на исправление заключенных в пенитенциарном учреждении, а также существует ли возможность улучшить систему приведения в исполнение наказаний в виде лишения свободы до того момента, когда данная мера в нынешнем виде исчезнет из существующих правовых систем? Авторы рассуждают также вопрос: Можно ли человека научить жить в обществе согласно одобряемым этим обществом правилам, несмотря на то, что осужденный часто несколько лет находился в изоляции от него? 
